\title{
本態性高血圧症の体位血圧反射について
}

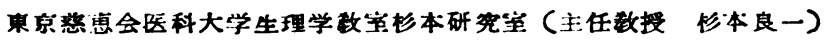 \\ 佐䍀鈴木将夫 \\ (受付昭和 29 年 3 月 24 日)
}

本態性高血圧症の成因については，從来枚挙て 息のない多数の研究があるにも拘らす，之の成因 は今日殆んぞ全く不明といつて差しつかえない。 しかしながら近時の医学の進歩はその成因関与 る多くの事実を明らかにしつつあり，例えば素 因，堅性因子，內分䎵性因子及で神释性因子の関 与についてとくに强調されている。

私どもは体態性高血压症成立.の初期飞は神経性 因子，とくに自律神経系の関与が重大な意義を有 ナっであららと考えて 2，3 の実験を行つたので 報告したい。

本態性高血压症の患者が自律神経系不安定狀態 Кあるととは, 古くより主張され, 特飞 Kilin (1926), Mies, Kocher (1929) らによつて強 調されているが，最近では松本らが第 16 回日本 循環器病学会の高血圧の成因に関する宿題報告で も興味ある事実を述へてている。即ち, 高血匠を伴 ら頭部戦稘者は, 伴なわないものに比して, 間腦 症狀が著明であり、な招少つ, 卧位より立位への 体位変換試験では，著明な血圧変動を示すといら ととである。とれはまた一般高血圧患者が体位変 換てよつて著明な血圧変動を示す事実とよく一致 し, 高血圧症の成因に腦性因子の関与していると とを踣示している。

一方体位血圧反射は血圧調節機能，ひいては自 律神経中框機能の調応の良否を示す一示標として 疲学を検出する目的で橋本らが考案したものであ ろが, 私どもは教室の吉岡らの実験にならつて, 自律神释系不安定狀態検出の一助として本法を利 用した。

本実験は昭和 28 年 6 月 8 日から全月 13 日ま ボの間に行つたもので, 国立国府台病院高血圧研 究班が古川電機精銅所工員の調查を行つた時, そ の病態生理部門を担当して行つたるのである。

\section{实皓 方 法}

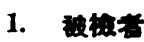

被検者第 1 表に示すよ5に總数 23 名でその 5ち本態性高血圧者は 11 名, 正常血圧者は 12 名である。いずれも尿中の蛋白は陰性である。被 検者は日光の古河電機精銅所の工員 3,000 名の中 からます 30 才以上 1,902 名を選び, このなかか ら at random K 23 名の高血圧者と正常者を 選出したものである。同精銅所は海拔 700 米の高 地にあり, 寒気が強く, 被梌者のすへてはこの近 辺几平均 15 年以上居住し, しか子 10 年以上の 勤続年限を有し，現在な就役中のものである。

被検者の一般的事項につんては第 1 表に示した が，平均年令江正常血圧者群（A 群） 40 才，本 態性高血圧者群 (B 群) 41 才, 身長平均は $\mathrm{A}$ 群 160 粴, B 群 161 糎, 体重平均は A 群 $54 \mathrm{~kg}$, $B$ 群 $56 \mathrm{~kg}$ であつた。学歷は両群何れもすへてて 高小卒程度で, 労働條件も大体同程度のものを選 んである。被検者の日光居住期間は最高 43 年, 最低 10 年, 平均 21 年。睡眠時間は 8〜10 時 間, 食事の特徴としては山地ではあるが魚類を好 み, つんで野菜, 肉類の順である。嗜好品として は酒類は殆んぞ好まず, 煙草は 1 日 10 本程度で あつた。

な被検者の高血圧に対する遗伝的関係は A 群ではみとめられるもの6名, B 群では 7 名で あつた。

\section{2. 体位血圧反射の榙盀方法}

とれは東大生理学教室に括いて疲労判定法とし て考案されたものを応用した。即ち体位栾換によ る安静時血圧の変動が恢復するまでの時間並びた 下降度を求めたのである。

その方法を具体的にのべると, 安靜仰卧位 10 分後血圧 (最高, 最低)を湘定し，次いで坐位を 


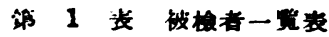

\begin{tabular}{|c|c|c|c|c|c|c|c|c|c|c|}
\hline & 番号 & 名 & 年命 & $\begin{array}{l}\text { 身長 } \\
\mathrm{cm}\end{array}$ & 体基 & $\begin{array}{l}\text { 居佳明 } \\
\text { (年) }\end{array}$ & 堲往柾 & 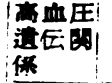 & 衁 $\underset{\mathrm{mmHg}}{\mathbb{E}}$ & 白 镭 跃 \\
\hline \multirow{5}{*}{ 対 } & 1 & * 山忠臣 & $42 !$ & 165 & 58 & 30 & $(-)$ & $(+)$ & $106-64$ & $(-)$ \\
\hline & 2 & 茜藤善平 & 49 & $159:$ & 50 & 28 & $(-)$ & $(-)$ & $126-70$ & $(-)$ \\
\hline & 3 & 平山次男 & 31 & 163 & 55 & 18 & $(-)$ & $(-)$ & $115-72$ & $(-)$ \\
\hline & 4 & 八木沢已之吉 & 35 & 158 & 62 & 15 & $\checkmark \Rightarrow y+$ & $(-)$ & $126-70$ & $(-)$ \\
\hline & 5 & 八木沢蔽郎 & 41 & 158 & 54 & 20 & 神経消 & $(-)$ & $108-68$ & $(-)$ \\
\hline \multirow{3}{*}{ 照 } & 6 & 佐藤哲三郎 & 37 & 159 & 55 & 18 & $(-)$ & $(+)$ & $104-66$ & $(-)$ \\
\hline & 7 & 竹沢長头 & 47 & 166 & 56 & 28 & $(-)$ & $(+) !$ & $138-102$ & $(-)$ \\
\hline & 8 & 小林驡太郎： & 49 & 163 & 58 & 33 & $(-)$ & $(+)$ & $134-80$ & $(-)$ \\
\hline \multirow[t]{4}{*}{ 群 } & 9 & 清 水正二 & 38 & 165 & 58 & 30 & 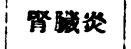 & $(-)$ & $134-84$ & $(-)$ \\
\hline & 10 & 融田㧕之吉 & 37 & 162 & 58 & 19 & $(-)$ & $(-)$ & $134-66$ & $(-)$ \\
\hline & 11 & 峑之井芳已 & 35 & 150 & 50 & 15 & $(-)$ & $(+)$ & $122-64$ & $(-)$ \\
\hline & 12 & 宫杉千万人 & 40 & 160 & 64 & 18 & $(-)$ & $(+)$ & $112-72$ & $(-)$ \\
\hline \multirow{4}{*}{ 高 } & 1 & 石川時头 & 46 & 165 & 53 & 34 & $(-)$ & $(+)$ & $208-112$ & $-\rightarrow$ \\
\hline & 2 & 倉 井 忠 & 38 & 157 & 53 & 15 & $(-)$ & $(+)$ & $172-108$ & 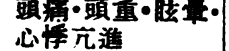 \\
\hline & 3 & 小野口三男 & 48 & 159 & 55 & 18 & $(-)$ & $(+)$ & $162-106$ & $(-)$ \\
\hline & 4 & 葡地奥什 & 54 & 152 & 60 & 40 & $(-)$ & $(+)$ & $170-118$ & 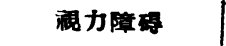 \\
\hline \multirow{2}{*}{ 血 } & 5 & 青木金方郎 & 49 & $162 !$ & 52 & 10 & $(-)$ & $(-)$ & $170-102$ & $(-)$ \\
\hline & 6 & 石沢長夲郎 & 44 & 158 & 53 & 20 & $(-)$ & $c-$ & $180-108$ & $(-)$ \\
\hline \multirow{2}{*}{ 圧 } & 7 & 茂名 勉 & 54 & 157 & 48 & 15 & $(-)$ & $(+)$ & $170-108$ & $(-)$ \\
\hline & 8 & 嬳辺善大， & 38 & 168 & 60 & 12 & 右助睡谈 & $c-$ & $170-118$ & 右用八こ少 \\
\hline \multirow[t]{3}{*}{ 群 } & 9 & 杉山破 & 48 & 149 & 45 & 17 & $(-)$ & $(+)$ & $*^{160-90}$ & 眉ノェリ・耳鸣y \\
\hline & 10 & 谷中电四郎 & 36 & 152 & 60 & 12 & & $(+)$ & $138-87$ & $(-)$ \\
\hline & 11 & 佐藤兼次郎 & 42 & 156 & 54 & 20 & & $(-)$ & $182-98$ & $(-)$ \\
\hline
\end{tabular}

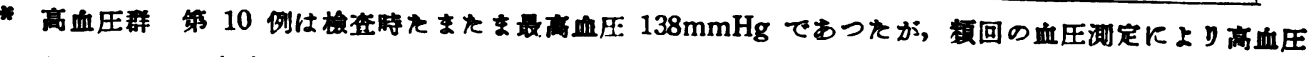
を示すことを碓瑟してある。

とらせ，血圧の安定をまつて最高最低血圧を湘定 し, 弗飞他動的飞坐位より臥位に調節椅子を用い て変位させ, 20 秒間隔で血圧つ最高值のみを 測 定する。かくして安靜仰卧位の血王値て戾つたの ちて再び他動的と坐位をとらせ, 15 秒間隔で血 压値が恢復するまで正確て最高血圧を測定する。

\section{实駼成績並ひに考寀}

A, B 群 23 名について安靜仰卧位 10 分後に 行つた体位血圧反射の成績は第 2 表に示した如く である。A 群も体位変換後の血珐の低下がく みられるが, 特飞 B 群ではその低下の度合が著 明で, しかも前值に復するまでの時間の長いとと が示されている。とれらの平均傎を因に示すと第 1 四の如くで, 高血王者群の体位血圧反射が強く 現われ，しか名恢復時閒の延長が明巨かとみとめ

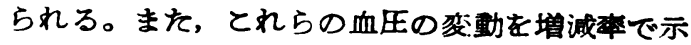
ナと第 2 表の右轌の如くで, やはり B 群は A 群 に比し降下度の強いととが示された。

体位血圧反射は血王調第機能，ひいては自律神 怪中框機能の調応の良否を示す一指標として，疲 労を検出する目的で橋本”が考案したものである が, 教室の吉岡, F栗”はとれをVegetative Labilität の椧出の一助として応用し, 頭部損賃 患者に自律神経中樞の失調のあるととを示した。 われわれも同じ意図のもとに本態性高血压症の被 検者にこの検出法を行い, 正常者群にくらべて, 血压の降下度強くかつ安靜時血圧て恢復する時間 の延長をみとめた。

橋本のいら初頭変動はA群では平均 $14 \mathrm{mmHg}$ ， B 群では $21 \mathrm{mmHg}$ で, B 群の恢復曲線は橋本 の D 型て近い㑯向をこつていろので， B 群は 
2 表 体位血江父射成結

\begin{tabular}{|c|c|c|c|c|c|c|c|c|c|c|c|c|c|c|c|}
\hline & 1 & 1 & 2 & 3 & 4 & 5 & 6 & 7 & 8 & 9 & 10 & 11 & 12 & $7+x_{1}$ & 549 \\
\hline IF. & 安静血压 & 106 & 126 & 115 & 126 & 108 & 112 & 10.4 & 138 & 134 & 132 & 134 & 122 & 121 & 11,0 \\
\hline 裳 & 南 传 & 88 & 108 & 99 & 108 & 94 & $10 ?$ & 94 & 128 & 112 & 122 & 118 & 110 & 107 & 88.4 \\
\hline & 15秒 & 90 & 113 & 100 & 115 & 104 & 110 & 98 & $1: 30$ & 120 & 128 & 124 & 115 & 111 & 9 i. 8 \\
\hline 孝 & 30 & 90 & 114 & 102 & 124 & 106 & $1: 0$ & 100 & 130 & 132 & 126 & $12: 2$ & 120 & 118 & $97.5^{\prime}$ \\
\hline 碓 & 45 & 92 & 118 & 104 & 124 & 108 & 124 & 100 & 130 & 135 & 126 & 12.4 & 124 & 117 & 56.6 \\
\hline ᄃ & 60 & 94 & 120 & 108 & 122 & 108 & 122 & 102 & 132 & $1: 8$ & 128 & 122 & 128 & 119 & 98.4 \\
\hline A & 75 & 94 & 120 & 108 & 124 & 110 & 122 & 102 & 132 & 140 & 126 & 124 & 128 & 119 & 98.4 \\
\hline 形 & 90 & 96 & 120 & 116 & 124 & 112 & 124 & 102 & 134 & 138 & 128 & 122 & 128 & 120 & 99.2 \\
\hline & & 1 & 2 & 3 & 4 & 5 & 6 & 7 & 8 & 9 & 10 & 11 & & 均 & 坮源陎 \\
\hline & 安靜血压 & 210 & 172 & 162 & 170 & 170 & 178 & 170 & 170 & 160 & 138 & 182 & & 166 & 100 \\
\hline 离 & 面㿻 & 196 & 138 & 132 & 142 & 144 & 154 & 154 & 146 & 128 & 112 & 150 & & 145 & 87.4 \\
\hline 血 & 15秒 & 202 & 139 & 138 & 154 & 142 & 164 & 168 & 152 & 134 & 124 & 158 & & 152 & 91.5 \\
\hline & 30 & 204 & 142 & 142 & 158 & 158 & 162 & 174 & 160 & 138 & 130 & 162 & & 158 & 95.2 \\
\hline 圷 & 45 & 208 & 146 & 146 & 160 & 164 & 160 & 174 & 162 & 132 & 130 & 164 & & 158 & 95.2 \\
\hline 者 & 60 & 210 & 152 & 146 & 164 & 162 & 164 & 176 & 168 & 132 & 128 & 168 & & 160 & 96.4 \\
\hline 群 & 75 & 208 & 158 & 146 & 164 & 160 & 162 & 172 & 162 & 134 & 128 & 176 & & 161 & 97.0 \\
\hline & 90 & 210 & 162 & 152 & 166 & 164 & 164 & 168 & 158 & 134 & 130 & 176 & & 162 & 97.5 \\
\hline$\widehat{B}$ & 105 & 208 & 160 & 158 & 166 & 166 & 164 & 178 & 158 & 140 & 130 & 174 & & 163 & 93. 2 \\
\hline 㻊 & 120 & 208 & 160 & 158 & 166 & 170 & 164 & 178 & 160 & 144 & 130 & 176 & & 164 & 98.9 \\
\hline & 135 & 206 & 160 & 158 & 166 & 170 & 168 & 178 & 162 & 140 & 130 & 176 & & 163 & 98.2 \\
\hline
\end{tabular}

A 群に比して自律神経中樞の機能尖調 度が穴進しているものと判断してさしつ か允ないと洘える。

更に安靜仰卧位 30 分攻ざ 60 分後に も A，B 群について同様の実験を行つ たととう，10 分後の実験結果とほ问 一の成績を得た。

\section{總括}

1）私どもは自覚症候のない本態性高 血圧症 11 名沉ついて体位血压反射孝行 ，次のよ5な成績在得た。

2）体位変換前後の血压の差注常者 群に比し高血圧者群に扣いて著るしく大 であり，乙心方安靜時血圧て恢復する時 閒の延骎在みとめた。

3）血厈恢復の型は橋本の D 型を示:

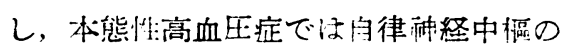
機能失調を汸していることが証明され た。
第 1 困体位血圧反射成耫

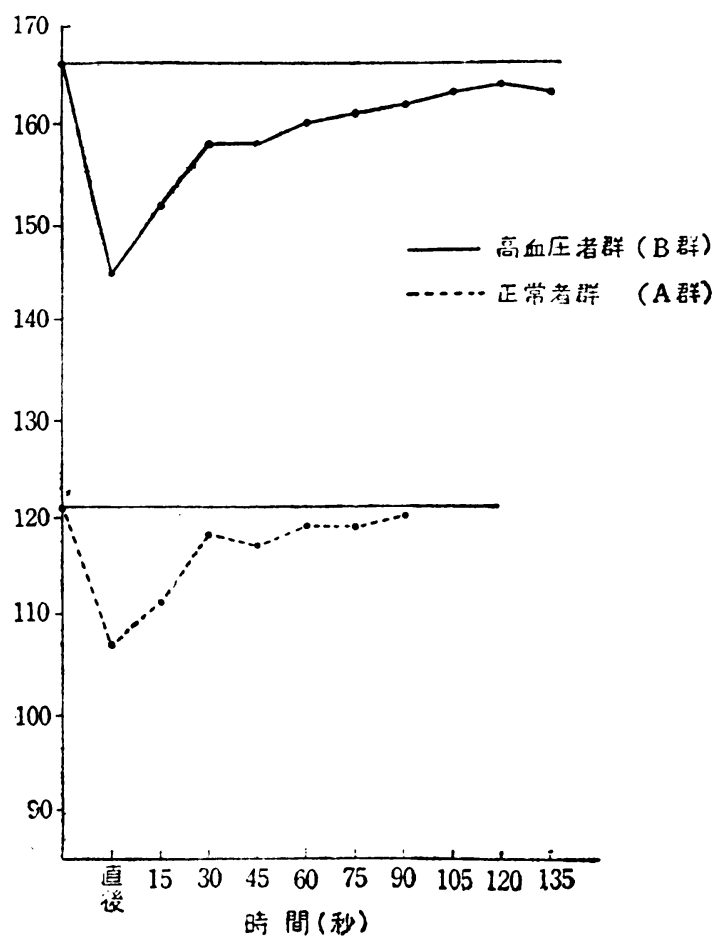




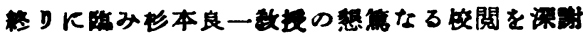

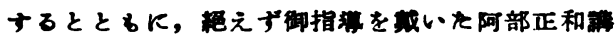

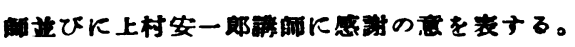

x 鰠

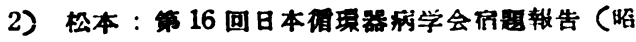
27)

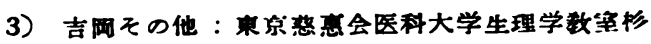
本研究室简文集, 1, 149, (昭 23,24 年)

1)柏本：医学々生物学 11，213，(昭 22） 